\title{
Cellulomonas bogoriensis sp. nov., an alkaliphilic cellulomonad
}

\author{
Brian E. Jones, ${ }^{1}$ William D. Grant, ${ }^{2}$ A. W. Duckworth, ${ }^{2}$ Peter Schumann, ${ }^{3}$ \\ Norbert Weiss ${ }^{3}$ and Erko Stackebrandt ${ }^{3}$
}

Correspondence

Brian E. Jones

bjones@genencor.com

\author{
${ }^{1}$ Genencor International BV, Archimedesweg 30, 2333 CN Leiden, The Netherlands \\ ${ }^{2}$ Department of Infection, Immunity and Inflammation, University of Leicester, PO Box 138, \\ Leicester LE1 9HN, UK \\ ${ }^{3} \mathrm{DSMZ}$ - Deutsche Sammlung von Mikroorganismen und Zellkulturen GmbH, Mascheroder \\ Weg 1b, 38124 Braunschweig, Germany
}

\begin{abstract}
An alkaliphilic, slightly halotolerant, chemo-organotrophic, Gram-positive, rod-shaped bacterium, strain $69 \mathrm{~B} 4^{\top}$, was isolated from the sediment of the littoral zone of Lake Bogoria, Kenya.

Phylogenetically, it is a member of the genus Cellulomonas, showing less than $97.5 \%$ sequence similarity to the type strains of other Cellulomonas species. The highest level of similarity, albeit moderate, was found with respect to Cellulomonas cellasea DSM 20118 ${ }^{\top}$. Chemotaxonomic properties confirm the $16 \mathrm{~S}$ rRNA gene-based generic affiliation, i.e. a DNA $\mathrm{G}+\mathrm{C}$ content of 71.5 mol\%, anteiso- $C_{15: 0}$ and $C_{16: 0}$ as the major fatty acids, MK- $9\left(\mathrm{H}_{4}\right)$ as the major isoprenoid quinone, a peptidoglycan containing L-ornithine as the diamino acid and D-aspartic acid in the interpeptide bridge and phosphatidylglycerol as the only identified main polar lipid. The strain is aerobic to facultatively anaerobic, being capable of growth under strictly anaerobic conditions. Optimal growth occurs between $\mathrm{pH}$ values $9 \cdot 0$ and $10 \cdot 0$. On the basis of its distinct phylogenetic position and metabolic properties, strain $69 \mathrm{~B} 4^{\top}$ represents a novel species of the genus Cellulomonas, for which the name Cellulomonas bogoriensis sp. nov. is proposed. The type strain is $69 \mathrm{~B} 4^{\top}\left(=\mathrm{DSM} 16987^{\top}=\mathrm{CIP} 108683^{\top}\right)$.
\end{abstract}

The genus Cellulomonas is a member of the suborder Micrococcineae, order Actinomycetales, class Actinobacteria (Stackebrandt et al., 1997), being related to Oerskovia, and, more distantly, to Terrabacter, Rarobacter and relatives (Schumann et al., 2001; Stackebrandt et al., 2002). Cellulomonas contains 12 species, only one of which, Cellulomonas xylanilytica, has been described recently (Rivas et al., 2004). Most species are phylogenetically well separated, $C$. xylanilytica LMG $21723^{\mathrm{T}}$ and Cellulomonas humilata ATCC $25174^{\mathrm{T}}$ being the most closely related pair of type strains (99\% 16S rRNA gene sequence similarity, $36 \%$ DNA-DNA reassociation; Rivas et al., 2004).

Strain $69 \mathrm{~B} 4^{\mathrm{T}}$ was isolated from a sample of sediment and water from the littoral zone of Lake Bogoria, at Acacia Camp $\left(0^{\circ} 12^{\prime} \mathrm{N} 36^{\circ} 07^{\prime} \mathrm{E}\right)$, Kenya on 10 October 1988 . The water temperature was $33^{\circ} \mathrm{C}$, the $\mathrm{pH}$ was 10.5 and the conductivity was $44 \mathrm{mS} \mathrm{cm}^{-1}$. The strain was partially characterized during a broad phylogenetic survey of sodalake alkaliphiles (Duckworth et al., 1996) and was tentatively

Published online ahead of print on 1 April 2005 as DOI 10.1099/ ijs.0.63646-0.

The GenBank/EMBL/DDBJ accession number for the 16S rRNA gene sequence of strain $69 B 4^{\top}$ is $\mathrm{X} 92152$. placed in the Arthrobacter/ Terrabacter region of the dendrogram based on 16S rRNA gene sequences (no Cellulomonas spp. sequences were included for comparison). Later, the strain was sent to the identification service of the DSMZ for cell-wall analyses to confirm its affiliation to the genus Cellulomonas. Since partial identification (Duckworth et al., 1996) highlighted its isolated phylogenetic position, perhaps indicative of a novel species, the characterization was extended to allow proper taxonomic description.

Strain $69 \mathrm{~B} 4^{\mathrm{T}}$ was isolated at $37^{\circ} \mathrm{C}$ on an alkaline casein medium containing the following $\left(\mathrm{g} \mathrm{l}^{-1}\right)$ : glucose (10), Difco peptone (5), Difco yeast extract (5), $\mathrm{K}_{2} \mathrm{HPO}_{4}(1)$, $\mathrm{MgSO}_{4} \cdot 7 \mathrm{H}_{2} \mathrm{O}(0 \cdot 2), \mathrm{NaCl}(40), \mathrm{Na}_{2} \mathrm{CO}_{3}(10)$, casein (20) and agar (20). Cultivation was done in glucose alkaline medium (GAM) consisting of two parts. GAM solution A contained the following, dissolved in $800 \mathrm{ml}$ distilled water and sterilized: glucose (10 g), Difco peptone $(5 \mathrm{~g})$, Difco yeast extract $(5 \mathrm{~g}), \mathrm{K}_{2} \mathrm{HPO}_{4}(1 \mathrm{~g})$ and $\mathrm{MgSO}_{4} \cdot 7 \mathrm{H}_{2} \mathrm{O}$ $(0 \cdot 2 \mathrm{~g})$. GAM solution $\mathrm{B}$ contained $40 \mathrm{~g} \mathrm{NaCl}$ and $10 \mathrm{~g}$ $\mathrm{Na}_{2} \mathrm{CO}_{3}$ dissolved in $200 \mathrm{ml}$ distilled water and sterilized. The two solutions were then mixed. Solid medium was prepared by adding agar $(2 \%, w / v)$ to GAM solution A before sterilization (Duckworth et al., 1996). The cultural properties are indicated in the species description. Standard 
Table 1. Cultural and metabolic properties that distinguish strain $69 \mathrm{~B} 4^{\top}$ from Cellulomonas species

Taxa: 1, strain 69B4 ${ }^{\mathrm{T}}$; 2, C. flavigena; 3, C. fermentans; 4, C. persica; 5, C. iranensis; 6, C. biazotea; 7, C. uda ; 8, C. fimi; 9, C. gelida; 10, C. hominis; 11, C. humilata; 12, C. cellasea; 13, C. xylanilytica. Data are from Stackebrandt \& Kandler (1979), Bagnara et al. (1985), Funke et al. (1995), Collins \& Pascual (2000), Elberson et al. (2000), Schumann et al. (2001) and Rivas et al. (2004). Symbols: ND, not determined; w, weak.

\begin{tabular}{|c|c|c|c|c|c|c|c|c|c|c|c|c|c|}
\hline Characteristic & 1 & 2 & 3 & 4 & 5 & 6 & 7 & 8 & 9 & 10 & 11 & 12 & 13 \\
\hline Catalase & + & + & - & ND & ND & + & + & + & + & + & - & + & \\
\hline Motility & + & + & - & + & + & + & - & + & + & + & - & - & - \\
\hline Nitrate reduction & - & + & + & + & + & + & + & + & + & + & - & + & + \\
\hline Urease & - & - & - & + & + & - & - & - & - & - & - & - & - \\
\hline DNase & + & - & + & + & + & - & + & ND & + & + & ND & - & ND \\
\hline $\begin{array}{l}\text { Gelatin hydrolysis } \\
\text { Utilization of: }\end{array}$ & + & + & + & $\mathrm{W}$ & + & + & + & + & + & + & $\mathrm{W}$ & - & + \\
\hline Mannitol & - & - & + & ND & ND & - & - & - & - & - & + & + & - \\
\hline Ribose & - & + & - & - & - & - & - & - & - & - & $\mathrm{W}$ & - & - \\
\hline D-Raffinose & - & - & + & - & - & + & - & - & - & + & $\mathrm{W}$ & - & + \\
\hline Rhamnose & $\mathrm{W}$ & - & - & ND & $\mathrm{ND}$ & + & - & - & - & + & + & - & + \\
\hline Peptidoglycan type & $\begin{array}{r}\text { L-Orn- } \\
\text { D-Asp }\end{array}$ & $\begin{array}{c}\text { L-Orn- } \\
\text { D-Asp }\end{array}$ & $\begin{array}{r}\text { L-Orn- } \\
\text { D-Asp }\end{array}$ & $\begin{array}{l}\text { L-Orn- } \\
\text { D-Asp }\end{array}$ & $\begin{array}{c}\text { L-Orn- } \\
\text { D-Asp }\end{array}$ & $\begin{array}{c}\text { L-Orn- } \\
\text { D-Glu }\end{array}$ & $\begin{array}{c}\text { L-Orn- } \\
\text { D-Glu }\end{array}$ & $\begin{array}{c}\text { L-Orn- } \\
\text { D-Glu }\end{array}$ & $\begin{array}{c}\text { L-Orn- } \\
\text { D-Glu }\end{array}$ & $\begin{array}{c}\text { L-Orn- } \\
\text { D-Glu }\end{array}$ & $\begin{array}{c}\text { L-Orn- } \\
\text { D-Glu }\end{array}$ & $\begin{array}{c}\text { L-Orn- } \\
\text { D-Glu }\end{array}$ & $\begin{array}{r}\text { L-Orn- } \\
\text { D-Glu }\end{array}$ \\
\hline
\end{tabular}

physiological tests were carried out according to the methods described by Smibert \& Krieg (1994). Acid production from carbon sources and enzyme activities were studied using the API $50 \mathrm{CH}$, API ZYM and API Coryne substrate panels (bioMérieux). Antibiotic sensitivity was tested by using the disc-diffusion method (Oxoid). The results are summarized in Table 1 and in the species description. Sequence analysis of the 16S rRNA gene was performed as described by Duckworth et al. (1996). The sequence (X92152) was reanalysed (Rainey et al., 1996) because of the presence of some ambiguous nucleotides. Chemotaxonomic properties were investigated as described by Groth et al. (1999) and are indicated in the species description. Despite being phylogenetically coherent, members of Cellulomonas exhibit differences in terms of the amino acid composition of peptidoglycan (Schleifer \& Kandler, 1972; Fiedler \& Kandler, 1973). Whilst four type strains and strain $69 \mathrm{~B} 4^{\mathrm{T}}$ contain D-aspartic acid as the interpeptide bridge, the other species contain D-glutamic acid. The distribution does not parallel the phylogenetic relatedness of the strains (Fig. 1).

The pairwise 16S rRNA gene similarity values determined for strain $69 \mathrm{~B} 4^{\mathrm{T}}$ and other type strains of Cellulomonas species are moderate $(95 \cdot 0-97 \cdot 2 \%$ similarity), the highest value being that obtained with C. cellasea DSM $20118^{\mathrm{T}}$ $(97 \cdot 2 \%)$. Neighbour-joining and distance matrix analyses (Saitou \& Nei, 1987; De Soete, 1983) place strain 69B4 ${ }^{\mathrm{T}}$ adjacent to Cellulomonas fermentans DSM $3133^{\mathrm{T}}(96 \cdot 4 \%$ sequence similarity), but strain $69 \mathrm{~B} 4^{\mathrm{T}}$ and C. cellasea DSM $20118^{\mathrm{T}}$ have a shorter added branch distance than the former pair of strains. Strain $69 \mathrm{~B} 4^{\mathrm{T}}$ shares with strain DSM $3133^{\mathrm{T}}$ the same peptidoglycan type but differs from this strain in terms of nitrate reduction and the use of mannitol and raffinose. The phenotypic differences between strain
$69 \mathrm{~B} 4^{\mathrm{T}}$ and strain DSM $20118^{\mathrm{T}}$ are even greater, in addition to the different peptidoglycan type. On the basis of a combination of phylogenetic distinctness, differences in diagnostic amino acids in peptidoglycan, and metabolic traits, we conclude that strain $69 \mathrm{~B} 4^{\mathrm{T}}$ represents a novel species, for which the name Cellulomonas bogoriensis sp. nov. is proposed.

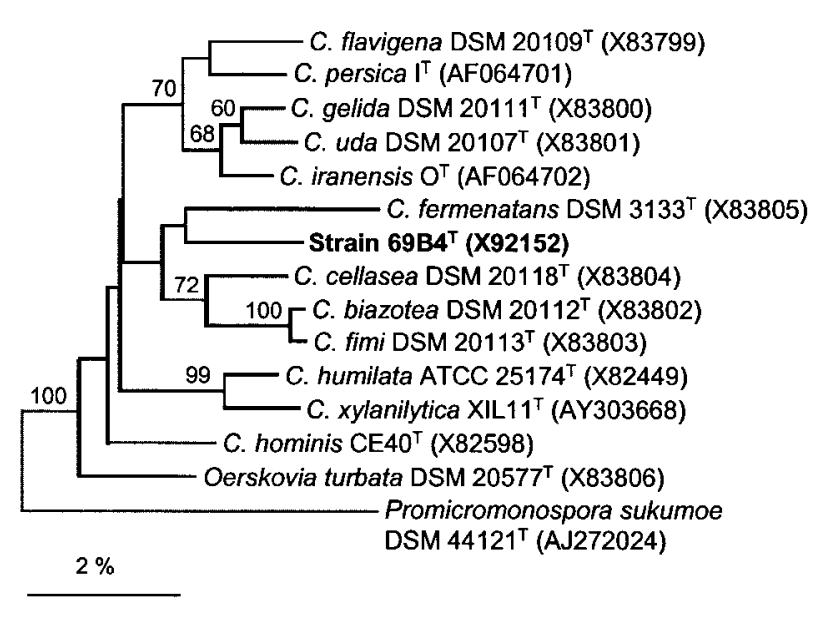

Fig. 1. Phylogenetic relatedness of strain $69 B 4^{\top}$ and type strains of Cellulomonas species, based on 16S rRNA gene sequence comparison. Beutenbergia cavernae DSM $12333^{\top}$ (GenBank accession no. Y18378) and Jonesia denitrificans DSM 20603 ${ }^{\top}$ (X83811) served as a root (not shown). The dendrogram was generated by using neighbour-joining analysis (Saitou \& Nei, 1987). Numbers within the dendrogram indicate percentages of occurrence of the branching order in 500 bootstrapped trees (only values of $50 \%$ and above are shown). Bar, 2 substitutions per $100 \mathrm{nt}$. 


\section{Cellulomonas bogoriensis sp. nov.}

Cellulomonas bogoriensis (bo.go.ri.en'sis. N.L. fem. adj. bogoriensis pertaining to Lake Bogoria, Kenya).

Fresh cultures consist of Gram-positive, slender, generally straight and rod-shaped cells, each approximately $0 \cdot 5-$ $0.7 \mu \mathrm{m}$ in size. Primary mycelium is not formed. Older cultures contain mainly short rods and coccoid cells; 'V'forms and pairs may occur. Primary branching not observed. On alkaline GAM agar, colonies are opaque, glistening, pale yellow, circular and convex or domed, the margins are entire, and they are about $2 \mathrm{~mm}$ in diameter after $2-3$ days at $37^{\circ} \mathrm{C}$. Colonies are viscous or slimy and tend to clump when scraped with a loop. On neutral tryptone soy agar (Oxoid), growth is less vigorous, colonies are translucent and yellow, and generally $<1 \mathrm{~mm}$ in diameter. The temperature range for growth is $20-37^{\circ} \mathrm{C}$, with an optimum around $30-37^{\circ} \mathrm{C}$. No growth occurs at 15 or $45^{\circ} \mathrm{C}$. Alkaliphilic and slightly halotolerant. Growth occurs at $\mathrm{pH}$ values between $6 \cdot 0$ and $10 \cdot 5$, with an optimum around $\mathrm{pH} 9-10$. No growth occurs at $\mathrm{pH} 11$ or $\mathrm{pH} 5 \cdot 5$. Growth below pH 7 is less vigorous and less abundant. Growth occurs in medium containing $0-8 \cdot 0 \%(\mathrm{w} / \mathrm{v})$ $\mathrm{NaCl}$. Chemo-organotrophic. Growth occurs on complex substrates such as yeast extract and peptone. Facultatively anaerobic; acid is produced aerobically and anaerobically (API $50 \mathrm{CH}$ ) from the following: L-arabinose, D-xylose, D-glucose, D-fructose, D-mannose, cellobiose, maltose, sucrose, trehalose, gentiobiose, D-turanose, D-lyxose, rhamnose (weak) and 5-ketogluconate (weak). Utilizes amygdalin, arbutin, salicin and aesculin. Unable to utilize ribose, lactose, galactose, melibiose, D-raffinose, glycogen, glycerol, erythritol, inositol, mannitol, sorbitol, xylitol, arabitol, gluconate or lactate. Hydrolyses starch, gelatin, casein, carboxymethylcellulose and amorphous cellulose. The following enzymes are produced (API ZYM, API Coryne): C4-esterase, C8-esterase, leucine arylamidase, $\alpha$-chymotrypsin, $\alpha$-glucosidase, $\beta$-glucosidase and pyrazinamidase. Susceptible to ampicillin $(25 \mu \mathrm{g})$, chloramphenicol $(25 \mu \mathrm{g})$, erythromycin $(5 \mu \mathrm{g})$, fusidic acid $(10 \mu \mathrm{g})$, methicillin $(10 \mu \mathrm{g})$, novobiocin $(5 \mu \mathrm{g})$, streptomycin $(10 \mu \mathrm{g})$, tetracycline $(25 \mu \mathrm{g})$, sulphafurazole $(100 \mu \mathrm{g})$, oleandomycin $(5 \mu \mathrm{g})$, polymyxin (300 IU), rifampicin $(2 \mu \mathrm{g})$, vancomycin $(30 \mu \mathrm{g})$ and bacitracin (10 IU). Resistant to gentamicin $(10 \mu \mathrm{g})$, nitrofurantoin $(50 \mu \mathrm{g})$, nalidixic acid $(30 \mu \mathrm{g})$, sulphamethoxazole $(50 \mu \mathrm{g})$, trimethoprim $(2 \cdot 5 \mu \mathrm{g})$, penicillin G (1 IU), neomycin $(30 \mu \mathrm{g})$ and kanamycin $(30 \mu \mathrm{g})$. The murein contains the amino acids L-ornithine and D-aspartic acid as diagnostic amino acids (L-Orn-D-Asp type, variation $\mathrm{A} 4 \beta)$. The main menaquinone is $\mathrm{MK}-9\left(\mathrm{H}_{4}\right)$. Major fatty acids $(>1.0 \%)$ are anteiso- $\mathrm{C}_{15: 0}(54.9 \mathrm{~mol} \%)$, $\mathrm{C}_{16: 0} \quad(12.9 \mathrm{~mol} \%)$, iso- $\mathrm{C}_{15: 0} \quad(5.5 \mathrm{~mol} \%)$, iso- $\mathrm{C}_{16: 0}$ $(5 \cdot 1 \mathrm{~mol} \%), \mathrm{C}_{14: 0}(8 \cdot 8 \mathrm{~mol} \%)$, anteiso- $\mathrm{C}_{15: 1}(4 \cdot 1 \mathrm{~mol} \%)$, iso- $\mathrm{C}_{14: 0}(2 \cdot 6 \mathrm{~mol} \%)$ and anteiso- $\mathrm{C}_{17: 0}(2 \cdot 8 \mathrm{~mol} \%)$. Phosphatidylglycerol is the only identified phospholipid; three unknown phospholipids occur as well. The DNA $\mathrm{G}+\mathrm{C}$ content of the type strain is $71 \cdot 5 \mathrm{~mol} \%$.
The type strain, $69 \mathrm{~B} 4^{\mathrm{T}}\left(=\mathrm{DSM} 16987^{\mathrm{T}}=\mathrm{CIP} 108683^{\mathrm{T}}\right)$, was isolated from the littoral zone of Lake Bogoria, Kenya, at Acacia Camp.

\section{Acknowledgements}

We appreciate the excellent technical assistance of Daan Meijer.

\section{References}

Bagnara, C., Toci, R., Gaudin, C. \& Belaich, J. P. (1985). Isolation and characterization of a cellulolytic microorganism, Cellulomonas fermentans sp. nov. Int J Syst Bacteriol 35, 502-507.

Collins, M. D. \& Pascual, C. (2000). Reclassification of Actinomyces humiferus (Gledhill and Casida) as Cellulomonas humilata nom. corrig., comb. nov. Int J Syst Evol Microbiol 50, 661-663.

De Soete, G. (1983). A least square algorithm for fitting additive trees to proximity data. Psychometrika 48, 621-626.

Duckworth, A. W., Grant, W. D., Jones, B. E. \& van Steenbergen, R. (1996). Phylogenetic diversity of soda lake alkaliphiles. FEMS Microbiol Ecol 19, 181-191.

Elberson, M. A., Malekzadeh, F., Yazdi, M. T., Kameranpour, N., Noori-Daloii, M. R., Matte, M. H., Shahamat, M., Colwell, R. R. \& Sowers, K. R. (2000). Cellulomonas persica sp. nov. and Cellulomonas iranensis sp. nov., mesophilic cellulose-degrading bacteria isolated from forest soils. Int J Syst Evol Microbiol 50, 993-996.

Fiedler, F. \& Kandler, O. (1973). Die Mureintypen in der Gattung Cellulomonas Bergey et al. Arch Mikrobiol 89, 41-50 (in German).

Funke, G., Ramos, C. P. \& Collins, M. D. (1995). Identification of some clinical strains of CDC coryneform group A-3 and A-4 bacteria as Cellulomonas species and proposal of Cellulomonas hominis sp. nov. for some group A-3 strains. J Clin Microbiol 33, 2091-2097.

Groth, I., Schumann, P., Martin, K., Schütze, B., Augsten, K., Kramer, I. \& Stackebrandt, E. (1999). Ornithinicoccus hortensis gen. nov., sp. nov., a soil actinomycete which contains L-ornithine. Int J Syst Bacteriol 49, 1717-1724.

Rainey, F. A., Ward-Rainey, N., Kroppenstedt, R. M. \& Stackebrandt, E. (1996). The genus Nocardiopsis represents a phylogenetically coherent taxon and a distinct actinomycete lineage: proposal of Nocardiopsaceae fam. nov. Int J Syst Bacteriol 46, 1088-1092.

Rivas, R., Trujillo, M. E., Mateos, P. F., Martínez-Molina, E. \& Velázquez, E. (2004). Cellulomonas xylanilytica sp. nov., a cellulolytic and xylanolytic bacterium isolated from a decayed elm tree. Int J Syst Evol Microbiol 54, 533-536.

Saitou, N. \& Nei, M. (1987). The neighbor-joining method: a new method for reconstructing phylogenetic trees. Mol Biol Evol 4, 406-425.

Schleifer, K. H. \& Kandler, O. (1972). Peptidoglycan types of bacterial cell walls and their taxonomic implications. Bacteriol Rev 36, 407-477.

Schumann, P., Weiss, N. \& Stackebrandt, E. (2001). Reclassification of Cellulomonas cellulans (Stackebrandt and Keddie 1986) as Cellulosimicrobium cellulans gen. nov., comb. nov. Int J Syst Evol Microbiol 51, 1007-1010.

Smibert, R. M. \& Krieg, N. R. (1994). Phenotypic characterization. In Methods for General and Molecular Bacteriology, pp. 607-655. Edited by P. Gerhardt, R. G. E. Murray, W. A. Wood \& N. R. Krieg. Washington, DC: American Society for Microbiology.

Stackebrandt, E. \& Kandler, O. (1979). Taxonomy of the genus Cellulomonas, based on phenotypic characters and deoxyribonucleic 
acid-deoxyribonucleic acid homology, and proposal of seven neotype strains. Int J Syst Bacteriol 29, 273-282.

Stackebrandt, E., Rainey, F. A. \& Ward-Rainey, N. L. (1997). Proposal for a new hierarchic classification system, Actinobacteria classis nov. Int J Syst Bacteriol 47, 479-491.
Stackebrandt, E., Schumann, P. \& Prauser, H. (2002). The family Cellulomonadaceae. In The Prokaryotes, 3rd edn, release 3.10. Edited by M. Dworkin, S. Falkow, E. Rosenberg, K. H. Schleifer \& E. Stackebrandt. New York: Springer. http://141.150.157.117:8080/ prokPUB/chaprender/jsp/showchap.jsp? chapnum $=440 \&$ initsec $=01$ 